\title{
Mungbean (Vigna radiata) intercropping enhances productivity of late season irrigated cotton in Punjab
}

\begin{abstract}
Muhammad Naeem Khan' ${ }^{1}$, Muhammad Shoaib ${ }^{2 *}$, Muhammad Saeed Ashraf ${ }^{1}$, Rafi Qamar ${ }^{3}$, Asrar Mahboob ${ }^{2}$, Sobia Ijaz ${ }^{1}$

${ }^{1}$ Agronomic Research Institute, Faisalabad, Pakistan

${ }^{2}$ Maize and Millets Research Institute, Yusafwala, Sahiwal, Pakistan

${ }^{3}$ Department of Agronomy, University of Sargodha, Sargodha, Pakistan

\section{Abstract}

The aim of this study was to assess the option of intercropping mungbean (MB) in late season cotton to enhance productivity of the system. Mungbean was intercropped with cotton under two planting techniques practiced in Punjab for cotton sowing. Treatments consist of mungbean broadcast in $75 \mathrm{~cm}$ spaced drilled cotton rows (IS ${ }_{1}$ ), alternative rows of cotton and mungbean ( $\left.\mathrm{IS}_{2}\right)$, two rows of mungbean between cotton rows $\left(\mathrm{IS}_{3}\right)$ while in fourth treatment (IS 4 ) two mungbean rows were sown on top of $105 \mathrm{~cm}$ wide double ridge-furrow (beds hereafter). Results showed that mungbean presence adversely affected the number of opened, total bolls plant ${ }^{-1}$, opened boll percentage and seed cotton yield in all intercropping systems. However in bed intercropping, cotton produced $21.84 \%$ higher seed cotton yield than sole cotton. Alike, number of pods plant $^{-1}$ and number of grains pod ${ }^{-1}$ of mungbean decreased in intercropping treatments compared to sole mungbean. On average, mungbean yield was $21.1 \%$ less in intercropping treatments than sole mungbean. Yield advantage indicated by LER and ATER values was observed in all intercropping treatments except in $\mathrm{IT}_{3}$ where ATER suggested disadvantage. Highest LER (1.92) and ATER (1.58) were recorded in IS 4 . Aggressivity value indicates that bed structure favoured the cotton growth compared to mungbean. All intercropping systems showed positive values of system productivity index and monitory advantage index. This study concludes that productivity of late season cotton could be better enhanced by sowing two rows of mungbean on top of the $105 \mathrm{~cm}$ wide cotton beds.
\end{abstract}

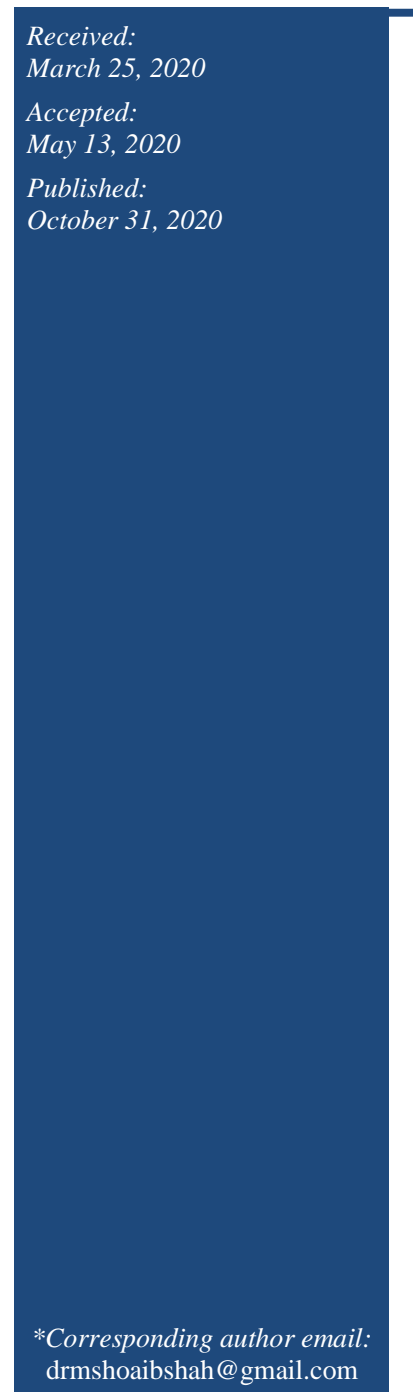

Keywords: Intercropping systems, LER, Seed cotton yield, System productivity index

\section{How to cite this:}

Khan MN, Shoaib M, Ashraf MS, Qamar R, Mahboob A and Ijaz S, 2020. Mungbean (Vigna radiata) intercropping enhances productivity of late season irrigated cotton in Punjab. Asian J. Agric. Biol. 8(4): 472-479. DOI: https://doi.org/10.35495/ajab.2020.03.187

This is an Open Access article distributed under the terms of the Creative Commons Attribution 3.0 License. (https://creativecommons.org/licenses/by/3.0), which permits unrestricted use, distribution, and reproduction in any medium, provided the original work is properly cited. 


\section{Introduction}

In Pakistan, total and per unit area cotton production has shown great variation in last few years. The greatest recession was witnessed in 2015-16 when total cotton production was 9,917 thousand bales that were $29 \%$ lower than previous year. On unit area bases cotton yield varied between 802 and $582 \mathrm{Kg}^{-}{ }^{-}$ ${ }^{1}$ (Ministry of Finance Pakistan, 2018). Some of the reasons to these upheavals are weather uncertainties, insect pests, diminishing fresh water availability and archaic crop growing techniques. Recommended time of sowing of cotton is from $15^{\text {th }}$ April to $15^{\text {th }}$ May. However in Punjab cotton planting seasons continues up to second week of June that produce lower yields (Ali et al, 2004). Late sowing affects the cotton growth and results in shortening of growing season. Sowing of cotton gets delayed due to unexpected weather conditions (rain), as observed in 2015 that prolonged the harvesting of wheat crop in whole cotton growing areas in Punjab (Anonymous, 2016). Moreover, > 85\% of the cotton growing farms are less than 5 hectares (Government of Pakistan, 2016) where subsistence type of farming is practiced. Farmers purchase agricultural inputs like quality seed, fertilizers, agrochemicals for next crop after selling of previous crop produce that takes time. Responding to the situation, farmers look for approaches that can make their farming system productive and sustainable.

Intercropping, a tool of agricultural biodiversity and sustainability, can provide yield stability against certain stress factors through temporal and spatial complements in small scale farming though evidence from large scale farming is limited. This approach is widely accepted strategy to deal with some of the major agricultural issue today including yield optimization, pest management, eco-degradation leading to sustainable agricultural system (Vandermeer, 1989; Lithourgidis et al., 2011b). Intercropping is quite suitable for low input, low mechanized farming like Pakistan where most of the farmers practice subsistence farming.

Wider inter-row spaces and slow early growth of cotton results in substantial land surface vacant in cotton field especially early in growing season. This space can beneficially be utilized by growing intercrops especially pulses. Short duration leguminous crops can enhance resource use both by grain production and nitrogen fixation by the roots (Jayakumar, 2008; Duchene et al., 2017). Furthermore, intercropping long and short duration crop species improve radiation absorption over time resulting in greater biomass production and its partitioning to yield (Abate and Alemayehu, 2018). Khan and Khaliq (2004) reported that intercropping accumulated higher net field benefits compared to sole cotton.

Mungbean (Vigna radiata L.) is an annual legume grown for its seeds in Pakistan where it is cooked as whole or split seed (dhal). This has previously been evaluated as an intercrop in cotton (Khan and Khaliq, 2004; Khan et al. 2001) and recorded advantage over sole cropping. However there is a dearth of information on fate of mungbean intercropped in late season cotton. This experiment was planned to investigate the possibility of mungbean intercropping in late season cotton. The specific objective of this study was to 1) investigate the behavior of intercrops in terms of yield and yield contributing parameters under different planting techniques 2) to compare the productivity the mungbean-cotton intercropping with sole crops 3) to study the competition among intercrops.

\section{Material and Methods}

Trials were conducted at Research Area of Fiber Crops, Agronomic Research Institute, AARI, Faisalabad (31.26 $\mathrm{N}^{\circ}$ and $73.06 \mathrm{E}^{\circ}$ ) during the years 2014 and 2015. Mean monthly precipitation and temperature at experimental site is depicted in figure1. During both the years, previous crop on the experimental site was wheat which was harvested on 26 April and 29 April in 2014 and 2015, respectively. Field at research area is flat and well drained with clay loam soil texture. Other soil chemical characteristics like EC $\left(\mathrm{dS} \mathrm{m} \mathrm{m}^{-1}\right), \mathrm{pH}$, organic matter $(\%)$, available phosphorus (ppm) and potash (ppm) in 2014 and 2015 were 1.77 and 1.81, 7.9 and 7.6, 0.80 and $0.82,8.5$ and 8.6 and 180 and 183, respectively. At first step, disc harrow was used to cut and invert the soil. The field was irrigated and when field reached at field capacity, seed bed was prepared by cultivating the field thrice by tractor mounted cultivator up to a depth of $30 \mathrm{~cm}$ which was followed by planking. Beds $\left(\mathrm{IS}_{4}\right)$ were prepared by tractor mounted bed shaper. Mungbean was intercropped with cotton in four different ways described as: ( $\left.\mathrm{IS}_{1}\right)$ cotton sown in $75 \mathrm{~cm}$ spaced rows + mungbean broadcast, $\left(\mathrm{IS}_{2}\right)$ cotton sown in $75 \mathrm{~cm}$ spaced rows + one row of mungbean between two rows of cotton, $\left(\mathrm{IS}_{3}\right)$ cotton sown in $75 \mathrm{~cm}$ spaced rows $+30 \mathrm{~cm}$ spaced two rows of mungbean between two 
rows of cotton and $\left(\mathrm{IS}_{4}\right)$ two rows of cotton sown on both sides of $105 \mathrm{~cm}$ wide bed $+30 \mathrm{~cm}$ spaced two rows of mungbean on top of bed.

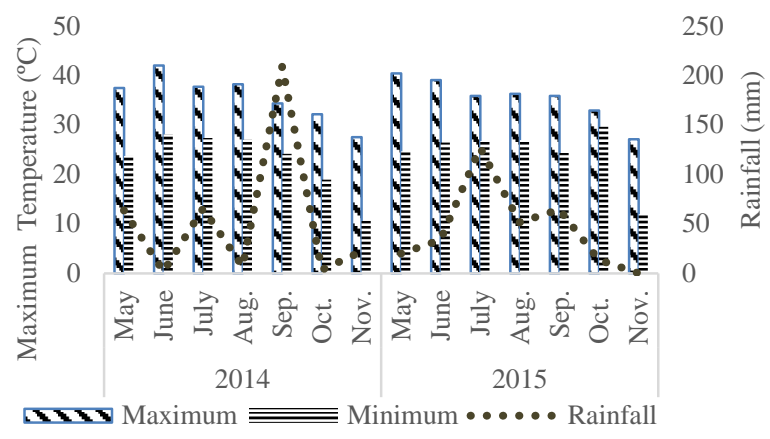

Figure-1. Mean monthly precipitation $(\mathrm{mm})$ and temperature $\left({ }^{\circ} \mathrm{C}\right)$ at experimental site during the growing seasons.

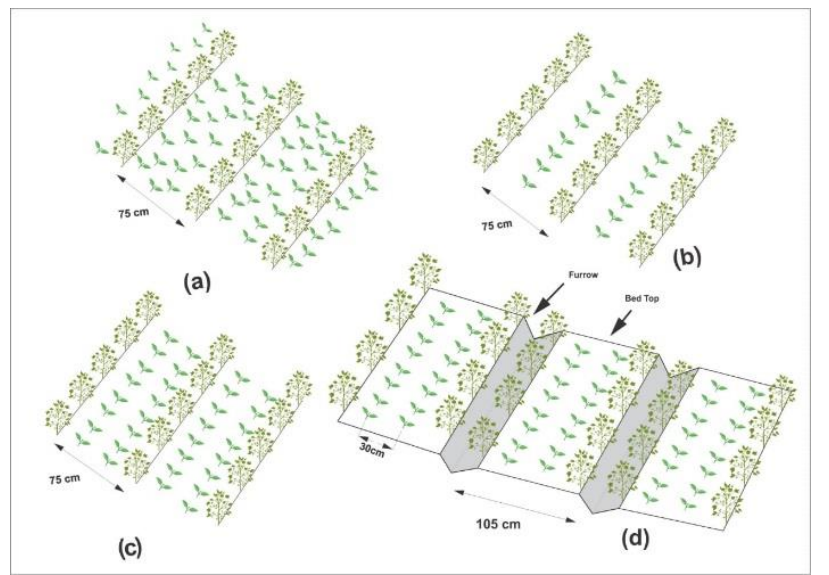

Figure-2. Illustration of intercropping systems

a) mungbean broadcast over $75 \mathrm{~cm}$ spaced cotton rows

b) one row of mungbean between $75 \mathrm{~cm}$ spaced cotton rows

c) two rows of mungbean between $75 \mathrm{~cm}$ spaced cotton rows

d) two rows of mungbean on bed top of double planted $105 \mathrm{~cm}$ wide cotton beds

Each experiment unit was replicated four times. Cotton was sown on 27 May and 24 May during 2014 and 2015, respectively. After 20 days of sowing thinning was done to maintain 6 cotton plants $\mathrm{m}^{-2}$. Mungbean was planted seven days after cotton sowing to facilitate cotton germination and early growth. Mungbean was sown at the rate of $20 \mathrm{~kg}$ seed ha-1 (90\% germination). Rows of both crops were sown by a man-drawn hand drill while in $\mathrm{IS}_{4}$ cotton was sown by dibbling. To meet the nutritional requirement of crops 200-115-95 kg NPK ha-1 was added to soil. Whole phosphorus and potassium were applied during land preparation while nitrogen was given in three splits $\left(1 / 3^{\text {rd }}\right.$ at sowing, $1 / 3^{\text {rd }}$ with first irrigation and $1 / 3^{\text {rd }}$ at bloom stage) to complement the peak crop need for nitrogen. Within 24 hours of cotton sowing, Pendimethalin 33 EC one litre acre ${ }^{-1}$ was sprayed as a pre-emergence weed control measure. Field was not irrigated during the time of co-existence of intercrops to hasten mungbean maturity. However field received $70.1 \mathrm{~mm}$ and $185.5 \mathrm{~mm}$ rainfall during this period in 2014 and 2015, respectively.

In each plot, five random plants from central rows of mungbean and cotton were selected for recording plant height, number of monopodia and sympodia branches, number of opened, unopened and total bolls of cotton. For mungbean, plant height, number of pods per plants, number of seeds per pod were recorded from selected plants. Mungbean was harvested manually with sickle on $12^{\text {th }}$ and $09^{\text {th }}$ August in 2014 and 2015, respectively. Mungbean plants were kept in the field for sun drying for 24 hours then were thrashed manually to separate grains from pods and weighed to record grain yield. After mungbean harvest, cotton was irrigated coupled with urea application. Later on, cotton was irrigated twice each of $7.5 \mathrm{~mm}$ deep. Cotton picking from whole plot was done on $10^{\text {th }}$ and $14^{\text {th }}$ November during 2014 and 2015 , respectively to record cotton seed yield. Subsequently wheat crop was sown in same field. Advantage of intercropping system over monocrops was assessed by land equivalent ratio (LER) calculated as under:

$$
\begin{gathered}
\text { Partial LER of cotton }=L_{c}=\frac{Y_{i c}}{Y_{s c}} \\
\text { Partial LER of Mungbean }=L_{m}=\frac{Y_{i m}}{Y_{s m}} \\
\text { Total LER }=L_{c}+L_{m}=\frac{Y_{i c}}{Y_{s c}}+\frac{Y_{i m}}{Y_{s m}}
\end{gathered}
$$

Where $Y_{\text {ic }}$ and $Y_{\text {im }}$ are the yield of cotton and mungbean in intercropping while $Y_{\mathrm{sc}}$ and $\mathrm{Y}_{\mathrm{sm}}$ are the yield of cotton and mungbean in sole crops, respectively. Area time equivalent ratio (ATER) is more realistic approach to measure the advantage of intercropping over monoculture system because it also takes into account the time taken by the intercrops in intercropping system. 


$$
\text { ATER }=\frac{\left(\mathrm{Y}_{\mathrm{ic}} \times \mathrm{T}_{\mathrm{ic}}\right)+\left(\mathrm{Y}_{\mathrm{im}} \times \mathrm{T}_{\mathrm{im}}\right)}{\mathrm{T}}
$$

Where $\mathrm{T}_{\mathrm{ic}}$ and $\mathrm{T}_{\mathrm{im}}$ are the duration (in days) of the cotton and mungbean in intercropping system and $\mathrm{T}$ is total duration (in days) of the intercropping system. ATER value $>1$ is yield advantage while value $<1$ indicates the disadvantage.

Aggressivity is a competition function that simply measures the relative yield increase of one crop compared to the other crop in intercropping system. In other words it measures the interspecific competition in intercropping by relating the yield changes of component crops and respective land occupancy (Li et al., 2001; Williams and McCarthy, 2001).

Aggressivity of cotton $\left(\mathrm{A}_{\mathrm{cm}}\right)=\frac{\mathrm{Y}_{\mathrm{cm}}}{\mathrm{Y}_{c c} \times \mathrm{Z}_{\mathrm{cm}}}-\frac{\mathrm{Y}_{\mathrm{mc}}}{\mathrm{Y}_{\mathrm{mm}} \times \mathrm{Z}_{m c}}$

Aggressivity of mungbean $\left(\mathrm{A}_{m c}\right)=\frac{\mathrm{Y}_{\mathrm{mc}}}{\mathrm{Y}_{m m} \times \mathrm{Z}_{\mathrm{mc}}}-\frac{\mathrm{Y}_{c m}}{\mathrm{Y}_{c c} \times \mathrm{Z}_{c m}}$

Where $Y_{\mathrm{cm}}$ and $Y_{\mathrm{mc}}$ are the yields of cotton and mungbean in mixtures, and $Y_{c c}$ and $Y_{m m}$ are yields in sole cropping, respectively. While $\mathrm{Z}_{\mathrm{cm}}$ and $\mathrm{Z}_{\mathrm{mc}}$ are the sown proportions of cotton and mungbean in intercropping system, respectively.

System productivity index (SPI) also evaluate intercrop performance by standardizing the yield of secondary (mungbean) crop in terms of primary crop (cotton) and is calculated as:

$$
S P I=\left(\frac{S_{c}}{S_{m}}\right) Y_{m}+Y_{c}
$$

Where Sc and Sm are the mean yield of monocrop cotton and mungbean while $\mathrm{Yc}$ and $\mathrm{Ym}$ are the mean yield of cotton and mungbean in intercropping.

Economic value of intercropping systems was evaluated by monetary advantage index (MAI) which were calculated according to Lithourgidis et al. (2011a).

$M A I=$ combined value of intercrops $\times \frac{L E R-1}{L E R}$

Combined value of intercrops was calculated as (Yc $\times$ $\mathrm{Pc})+(\mathrm{Ym} \times \mathrm{P})$, where $\mathrm{Yc}$ and $\mathrm{Ym}$ are the yields of cotton and mugbean in intercrops, respectively while $\mathrm{Pc}$ and $\mathrm{Pm}$ are the current price of cotton and mungbean in Pakistan Rupees (Rs.), respectively, in local market. The average prices (2014 and 2015) of cotton and mungbean were Rs. $2699 / 40 \mathrm{~kg}$ and Rs. $9358.5 / 100 \mathrm{~kg}$, respectively.

All the statistical analyses were performed through SAS 9.1.3 (SAS Institute Inc., Cary, NC, USA, 200203). Data of both years was pooled after conducting tests regarding heterogeneity of variances hence data presented here is the mean of two years. Least significant difference (LSD) test $(\mathrm{P}=0.05)$ was carried out to assess the effect of intercropping treatment on response variables.

\section{Results and Discussion}

\section{Mungbean}

Results reveal that intercropping treatments significantly $(\mathrm{P}<0.05)$ affected the mungbean yield and yield attributes.

All intercropping treatments recorded different $(\mathrm{P}<0.05)$ plant density $\mathrm{m}^{-2}$ compared to sole mungbean (Table 1) which resulted from planting geometry and presence of intercrop. Within the intercropping treatments, highest $(\mathrm{P}<0.05)$ mungbean population $\mathrm{m}^{-2}$ was achieved where two rows of mungbean $\left(\mathrm{IS}_{3}\right.$ and $\mathrm{IS}_{4}$ ) were intercropped with cotton while population $\mathrm{m}^{-2}$ in 1:1 row arrangement $\left(\mathrm{IS}_{2}\right)$ was lowest.

Plant height is a measure of plant competitive ability (Korres and Froud-Williams, 2002). Mungbean plants only in $\mathrm{IS}_{4}$ varied significantly $(\mathrm{P}<0.05)$ in height within intercropping system and from sole $\mathrm{MB}$. Interspecific competition from cotton owing to improved growing conditions for cotton coupled with severe intraspecific competition among mungbean plants due to higher plant density (Table 1) might have resulted in taller mungbean plants in this treatment.

Number of pods plant ${ }^{-1}$ were affected by intercropping treatments (Table 1). Compared to sole mungbean, all intercropping treatments produced lower number of pods plant ${ }^{-1}$ except $\mathrm{IS}_{2}$. Results are in agreement to that of Legwaila et al. (2012) and Morgado and Willey (2008) who reported similar results from maizecowpea intercropping system. Similarly Khan and Khaliq (2004) reported reduction in pod numbers in mungbean when intercropped with cotton in $80 \mathrm{~cm}$ spaced rows. Within the intercropping treatments maximum number of pods plant ${ }^{-1}$ were noted in $\mathrm{IS}_{2}$ that were $93.2 \%$ of sole mungbean. 
Table-1. Plant population $\left(\mathrm{m}^{-2}\right)$ plant height $(\mathrm{cm})$, number of pods plant $^{-1}$, number of grains pod ${ }^{-5}$ and grain yield $\left(\mathrm{kg} \mathrm{ha}^{-1}\right)$ of mungbean in cotton-mungbean intercropping system.

\begin{tabular}{|l|c|c|c|c|c|}
\hline $\begin{array}{c}\text { Intercropping } \\
\text { system }\end{array}$ & Plant population & Plant height & No. of pods & No. of grain & Grain yield \\
\hline $\mathrm{IS}_{1}$ & $11.07 \mathrm{~b}\left(-12.31^{*}\right)$ & $62.9 \mathrm{~b}(4.15)$ & $43.1 \mathrm{~b}\left(-18.69^{*}\right)$ & $7.62\left(-2.07^{*}\right)$ & $775 \mathrm{a}\left(-187.5^{*}\right)$ \\
\hline $\mathrm{IS}_{2}$ & $8.37 \mathrm{c}\left(-14.71^{*}\right)$ & $67.6 \mathrm{~b}(8.87)$ & $57.6 \mathrm{a}(-4.16)$ & $8.98(-0.70)$ & $812.5 \mathrm{a}\left(-150.0^{*}\right)$ \\
\hline $\mathrm{IS}_{3}$ & $16.62 \mathrm{a}\left(-6.76^{*}\right)$ & $64.7 \mathrm{~b}(5.97)$ & $35.1 \mathrm{bc}\left(-26.62^{*}\right)$ & $8.4(-1.28)$ & $850 \mathrm{a}(-112.50)$ \\
\hline $\mathrm{IS}_{4}$ & $17.11 \mathrm{a}\left(-6.29^{*}\right)$ & $84.6 \mathrm{a}\left(25.88^{*}\right)$ & $25.7 \mathrm{c}\left(-36.01^{*}\right)$ & $9.18(-0.5)$ & $600 \mathrm{~b}\left(-362.50^{*}\right)$ \\
\hline Sole mungbean & $23.38(\mathrm{control})$ & $58.8(\mathrm{control})$ & $61.8(\mathrm{control})$ & $9.68($ control $)$ & $962.5(\mathrm{control})$ \\
\hline LSD $_{\mathbf{0 . 0 5}}$ S & 1.62 & 11.80 & 14.66 & 1.35 & 148.56 \\
\hline LSD $_{\mathbf{0 . 0 5}} \Psi$ & 8.11 & 10.00 & 13.60 & $\mathrm{Ns}$ & 135.89 \\
\hline
\end{tabular}

Values within parenthesis with ${ }^{*}$ ' is the significant difference from control term

Lettering signifies the intercropping treatments. Means in each column sharing same letter are not significantly different $(\mathrm{P}<0.05)$. $\Psi=$ for comparison with control term, $\Omega=$ for comparison within intercropping treatment

Mungbean plants in $\mathrm{IS}_{4}$ produced lowest number of pods plant ${ }^{-1}$ that were only $41.59 \%$ of sole mungbean that could be attributed to higher plant density of mungbean and better growth of cotton plants hence increased competition for growth resources that lowered the number of pods plant ${ }^{-1}$ (Legwaila et al., 2012).

All intercropping treatments produced statistically similar number of grains pods ${ }^{-1}$ to sole mungbean except IS $_{1}$ where number of grains were $21.28 \%$ less than sole crop $(\mathrm{P}<0.05)$ and results are very much similar to Legwaila et al. (2012).

Intercropping systems affected the mungbean grain yield $(\mathrm{P}<0.05)$. However $\mathrm{IS}_{3}$ produced the grain yield similar to that of sole MB. Maximum MB yield reduction of $37.66 \%$ compared to sole $\mathrm{MB}$ was observed in $\mathrm{IS}_{4}$. Results are in agreement to that of Khan and Khaliq (2004) who also found mungbean yield reduction in cotton-mungbean intercropping system in Faisalabad. Within intercropping systems, 1:2 row configuration $\left(\mathrm{IS}_{3}\right)$ gave the maximum $\mathrm{MB}$ grain yield $\left(850 \mathrm{~kg} \mathrm{ha}^{-1}\right)$ however its difference from $\mathrm{IS}_{1}$ and $\mathrm{IS}_{4}$ was not significant while with that of $\mathrm{IS}_{4}$ was significant $(\mathrm{P}<0.05)$. This yield reduction in intercropping systems than sole mungbean is attributed to intraspecific competition from cotton plants on MB growth that affected yield contributor parameters of mungbean like number of pods plant ${ }^{-1}$, and number of grains pod ${ }^{-1}$ (Table 1). Likewise, Khan and Khaliq (2004) and Santalla et al. (2001) identified that yield reduction in intercropped bean was due to reduction in number of pods plant ${ }^{-1}$ and No. of seeds $\operatorname{pod}^{-1}$.

\section{Cotton}

Intercropping systems affected the yield and yield components of cotton (Table 2). Compared to sole cotton, cotton plants in $\mathrm{IS}_{3}$ were shorter than sole cotton $(\mathrm{P}<0.05)$ while all other intercropping systems did not differ significantly in this context. Within intercropping treatments, tallest cotton plants were observed in $\mathrm{IS}_{1}$ and $\mathrm{IS}_{4}$. Higher plant density and faster initial growth of mungbean in $\mathrm{IS}_{3}$ might have suppressed cotton growth in $\mathrm{IS}_{3}$. However better growing conditions for cotton in bed sowing $\left(\mathrm{IS}_{4}\right)$ reduced the severity of competition. Similarly, Metwally et al. (2012) recorded significant effect of corn intercropping system on cotton plant height.

Number of sympodias did not vary within intercropping treatments and between intercropping systems and sole cotton $(\mathrm{P}>0.05)$. Similar results have previously been reported by Khan et al. (2001) from cotton-mungbean and cotton-mashbean intercropping systems.

Highest number of opened bolls plant ${ }^{-1}(\mathrm{P}<0.05)$ were documented in sole cotton. Even the intercropping system with highest number of bolls plant ${ }^{-1}\left(\mathrm{IS}_{1}\right)$ produced $45.67 \%$ less open bolls plant ${ }^{-1}$ than sole cotton. While $\mathrm{IS}_{3}$ recorded $76.31 \%$ less number of bolls plant ${ }^{-1}$ than sole cotton. Results are in line with that of Safina et al. (2014) and Metwally et al. (2012) who also recorded lower number of opened bolls plant $^{-1}$ in intercropped cotton compared to sole cotton. 
Table-2. Plant height (cm), number of sympodias, number of opened, unopened and total bolls plant ${ }^{-1}$, open boll \% and seed cotton yield $\left(\mathrm{kg} \mathrm{ha}^{-1}\right)$ of cotton in cotton-mungbean intercropping system.

\begin{tabular}{|c|c|c|c|c|c|c|c|}
\hline $\begin{array}{c}\text { Intercropping } \\
\text { system }\end{array}$ & Plant height & $\begin{array}{c}\text { No. of } \\
\text { Sympodias }\end{array}$ & $\begin{array}{l}\begin{array}{l}\text { No. of opened } \\
\text { bolls }\end{array} \\
\end{array}$ & $\begin{array}{l}\text { No. of unopened } \\
\text { bolls }\end{array}$ & $\begin{array}{c}\text { Total No. of } \\
\text { bolls }\end{array}$ & Open boll & \begin{tabular}{|c|}
$\begin{array}{c}\text { Seed cotton } \\
\text { yield }\end{array}$ \\
\end{tabular} \\
\hline $\mathbf{I S}_{\mathbf{1}}$ & $\begin{array}{c}120.4 \mathrm{a} \\
(2.32)\end{array}$ & 11 & $\begin{array}{l}10.55 \mathrm{a} \\
(-8.87 *)\end{array}$ & $\begin{array}{c}3.65 \\
(2.90 *) \\
\end{array}$ & $\begin{array}{l}14.2 \mathrm{a} \\
(-5.96)\end{array}$ & $\begin{array}{c}74.61 \mathrm{a} \\
(-21.60 *)\end{array}$ & $\begin{array}{l}1088 b \\
(-100)\end{array}$ \\
\hline $\mathbf{I S}_{\mathbf{2}}$ & $\begin{array}{c}108.45 \mathrm{~b} \\
(-9.63)\end{array}$ & 9.93 & $\begin{array}{c}8.18 \mathrm{~b} \\
\left(-11.24^{*}\right)\end{array}$ & $\begin{array}{c}3.33 \\
\left(2.58^{*}\right)\end{array}$ & $\begin{array}{c}11.5 \mathrm{~b} \\
\left(-8.66^{*}\right)\end{array}$ & $\begin{array}{c}70.58 \mathrm{a} \\
(-25.64 *)\end{array}$ & $\begin{array}{l}1013 \mathrm{~b} \\
\left(-175^{*}\right)\end{array}$ \\
\hline $\mathbf{I S}_{\mathbf{3}}$ & $\begin{array}{c}80.05 \mathrm{c} \\
(-38.03 *)\end{array}$ & 9.3 & $\begin{array}{c}4.6 \mathrm{c} \\
(-14.82 *)\end{array}$ & $\begin{array}{c}4.03 \\
(3.28 *)\end{array}$ & $\begin{array}{c}8.63 \mathrm{c} \\
\left(-11.54^{*}\right)\end{array}$ & $\begin{array}{c}53.68 \mathrm{~b} \\
\left(-42.53^{*}\right)\end{array}$ & $\begin{array}{c}612.5 \mathrm{c} \\
(-575.0 *)\end{array}$ \\
\hline $\mathbf{I S}_{4}$ & $\begin{array}{c}126.13 \mathrm{a} \\
(8.04)\end{array}$ & 10.88 & $\begin{array}{l}10.05 \mathrm{a} \\
(-9.37 *)\end{array}$ & $\begin{array}{c}3.95 \\
(3.20 *)\end{array}$ & $\begin{array}{c}14 \mathrm{a} \\
(-6.16)\end{array}$ & $\begin{array}{c}71.71 \mathrm{a} \\
(-24.50 *)\end{array}$ & $\begin{array}{l}1512.5 \mathrm{a} \\
(325.0 *)\end{array}$ \\
\hline sole cotton & $\begin{array}{c}118.08 \\
\text { (control) }\end{array}$ & $\begin{array}{c}9.08 \\
\text { (control) }\end{array}$ & 19.42 (control) & 0.75 (control) & $\begin{array}{c}20.17 \\
\text { (control) }\end{array}$ & $\begin{array}{c}96.21 \\
\text { (control) }\end{array}$ & $\begin{array}{c}1187.5 \\
\text { (control) }\end{array}$ \\
\hline LSD $_{0.05} S$ & 15.463 & $\mathrm{~ns}$ & 7.1182 & 1.7565 & 7.1675 & 14.043 & 166.31 \\
\hline LSD $_{0.05} \Psi$ & 5.7825 & $\mathrm{~ns}$ & 1.4001 & Ns & 1.252 & 12.90 & 134.58 \\
\hline
\end{tabular}

Values within parenthesis with ${ }^{*}$ ‘ is the significant difference from control term

Lettering signifies the intercropping treatments. Means in each column sharing same letter are not significantly different $(\mathrm{P}<0.05)$. $\Psi=$ for comparison with control term, $S=$ for comparison within intercropping treatments

Reduced light interception by cotton in intercropping system might have resulted in reduced number of open boll. Likewise, total number of bolls plant ${ }^{-1}$ were maximum in sole cotton however its difference with $\mathrm{IS}_{1}$ and $\mathrm{IS}_{4}$ was not significant. Whereas lowest total number of bolls were recorded in treatment that involves two mungbean rows between cotton two rows $\left(\mathrm{IS}_{3}\right)$. On average, intercropping treatments produced $40 \%$ less total number of bolls plant ${ }^{-1}$ than sole cotton. Planting scheme that facilitated cotton growth i.e. $\mathrm{IS}_{4}$ has higher total number of boll and opened bolls plant ${ }^{-1}$.

Open boll percentage was greatest in sole cotton $(96.21 \%)$ than intercropping treatments $(\mathrm{P}<0.05)$. Opened boll ratio was $28.56 \%$ less in intercropping treatments compared to sole cotton. However, opened boll ratio remained alike amongst intercropping treatments except in $\mathrm{IS}_{3}$ where $46.32 \%$ bolls remained unopened $(\mathrm{P}<0.05)$ at the time of harvesting.

Seed cotton yield in different intercropping systems responded differently (Table 2). Seed cotton yield of cotton from intercropping treatments involving row sowing of cotton i.e. $\mathrm{IS}_{1}, \mathrm{IS}_{2}$ and $\mathrm{IS}_{3}$ was lower than sole cotton. Similarly Rusinamhodzi et al. (2006) reported lower seed cotton yield of intercropped cotton with cowpea compared to sole cotton. However, seed cotton yield in $\mathrm{IS}_{4}$ was greatest $(\mathrm{P}<0.05)$ that was $21.48 \%$ higher than sole cotton. This might be attributed to favorable planting arrangement for cotton growth in bed sowing as planting arrangements contribute to niche complementarity that benefits the intercrops. Another reason could be the better nitrogen flux from mungbean to cotton during co-existence of intercrops and better nitrogen availability to cotton after mungbean harvest as nodules on its roots degenerate. Rusinamhodzi et al. (2006) concluded that planting arrangement had an effect on transfer of nitrogen from legumes to cotton in intercropping system

\section{Intercropping competition and yield advantage}

The LER is the most widely used index which verifies resource utilization in mixture compared to sole cropping. In this study LER values were greater than 1 for all the intercropping systems that indicates yield advantage of mixtures over sole crops (Table 3). It also indicates that interspecific competition was less intense than intraspecific competition and niche complementarity befitted the intercrops (Lithourgidis et al., 2011b). Substantially higher LER (1.90) was recorded in $\mathrm{IS}_{4}$ followed by $\mathrm{IS}_{1}$. Considerably higher LER values from cotton-mungbean intercropping system has previously been reported by Khan and Khaliq (2004). The value of partial LER cotton $_{\text {greater }}$ than one in $\mathrm{IS}_{4}$ indicates that intercropping mungbean in bed sowing is more advantageous for cotton.

ATER, that compares the effectiveness of sole and intercrops in use of time and space to produce a given quantity of yield, also suggest the yield benefits from the cotton-mungbean intercropping (Table 3 ). Highest yield advantage $(\mathrm{P}>0.05)$ was recorded in $\mathrm{IS}_{4}$ while $\mathrm{IS}_{3}$ showed a yield disadvantage that may be attributed inappropriate planting arrangements instigated the competition among intercrops. 
Table-3. Land equivalent ratio (LER), Area time Equivalent Ration (ATER), aggressivity, system productivity Index and monetary advantage index of cotton-mungbean intercropping system

\begin{tabular}{|c|c|c|c|c|c|c|c|c|}
\hline \multirow{2}{*}{$\begin{array}{c}\text { Intercropping } \\
\text { system }\end{array}$} & \multicolumn{3}{|c|}{ LER } & \multirow{2}{*}{ ATER } & \multicolumn{2}{|c|}{ Aggressivity } & \multirow{2}{*}{ SPI } & \multirow{2}{*}{ MAI } \\
\hline & LERMB & LER $_{\text {cotton }}$ & LER $_{\text {total }}$ & & $\mathbf{A}_{\mathrm{MB}}$ & Acotton & & \\
\hline $\mathbf{I S}_{\mathbf{1}}$ & $0.80 \mathrm{a}$ & $0.92 \mathrm{~b}$ & $1.72 \mathrm{~b}$ & $1.31 \mathrm{~b}$ & -0.11 & 0.11 & $2046 \mathrm{a}$ & $55753 \mathrm{ab}$ \\
\hline $\mathbf{I S}_{\mathbf{2}}$ & $0.85 \mathrm{a}$ & $0.85 \mathrm{~b}$ & $1.70 \mathrm{~b}$ & $1.27 \mathrm{~b}$ & -0.01 & 0.01 & $2016 \mathrm{a}$ & $60857 \mathrm{a}$ \\
\hline $\mathbf{I S}_{3}$ & $0.88 \mathrm{a}$ & $0.52 \mathrm{c}$ & $1.40 \mathrm{c}$ & $0.95 \mathrm{~b}$ & 0.37 & -0.37 & $1661 \mathrm{~b}$ & $49537 \mathrm{~b}$ \\
\hline $\mathbf{I S}_{4}$ & $0.62 \mathrm{~b}$ & $1.28 \mathrm{a}$ & $1.90 \mathrm{a}$ & $1.58 \mathrm{a}$ & -0.65 & 0.65 & $2254 \mathrm{a}$ & $57795 \mathrm{ab}$ \\
\hline $\operatorname{LSD}_{0.05}$ & 0.142 & 0.114 & 0.176 & 0.130 & 0.17 & 0.17 & 314 & 9326 \\
\hline
\end{tabular}

Lettering signifies the intercropping treatments. Means in each column sharing same letter are not significantly different $(\mathrm{P}<0.05)$.

Aggressivity values suggest that competitiveness of the intercrops varied with change in their spatial arrangements (Table 3). Cotton was clearly more dominant with positive $\mathrm{A}_{\text {cotton }}$ values than mungbean in $\mathrm{IS}_{1}$ and $\mathrm{IS}_{2}$. Greater positive $\mathrm{A}_{\text {cotton }}$ value in $\mathrm{IS}_{4}$ conforms the yield and LER results for this intercropping system. Smaller ' $A$ ' values for the treatment when alternate rows of $\mathrm{MB}$ and cotton were planted suggest that in such spatial arrangement both crops are almost equally competitive and have similar capability to acquire nutrients. Dominancy of cotton in intercropping with different legumes has also been reported by Khan and Khaliq, (2004) and Aasim et al. (2008). Highest system productivity index value was recorded for $\mathrm{IS}_{4}$ that confirms the result of LER and ATER values (Table 3). It implies that this intercropping system has greater productivity and yield stability (Lithourgidis et al., 2011a; Agegnehu et al., 2006). While lesser SPI value for IS ${ }_{3}$ suggest less stability and productivity.

Monitory advantage index is an index of economic feasibility of intercropping. Values of MAI were positive for all the intercropping system of cotton with MB (Table 3). Highest MAI value of 60857 was recorded for alternative rows of both intercrops while the treatment with two rows of MB between cotton rows recorded least MAI value (49537). These results also suggest clear yield advantage in all intercropping system.

Taking into account the values of LER, ATER, A, SPI and MAI all the intercropping system recorded clear yield advantage over sole cropping possibly due to better resource utilization.

\section{Conclusion}

Intercropping mungbean in late sown cotton is a valuable option to increase the productivity and income of cotton growers. Though cotton yield was reduced in most of intercropping system studied however, this yield reduction was compensated by added advantage from mungbean grain yield. Competitive ability of the intercrops changed with change in their spatial arrangement in field. LER and other competition indices suggest that highest yield advantage was recorded when two rows of mungbean were intercropped on the top of $75 \mathrm{~cm}$ wide cotton bed.

Disclaimer: None.

Conflict of Interest: None.

Source of Funding: None.

\section{References}

Aasim M, Umer EM and Karim A, 2008. Yield and competition indices of intercropping cotton (Gossypiumhirsutum L.) using different planting patterns. Tarim. Bilim. Derg. 14: 326-333.

Abate M and Alemayehu G, 2018. Biological Benefits of Intercropping Maize (Zea mays L) with Fenugreek, Field Pea and Haricot Bean Under Irrigation in Fogera Plain, South Gonder Zone, Ethiopia. Agric. Forest. Fish. 7: 19-35.

Ali M, Mohy-Ud-Din Q, Ali MA, Sabir S and Ali L, 2004. Cotton yield as influenced by different sowing dates under the climatic conditions of Vehari-Pakistan. Int. J. Agric. Biol. 6: 644-646. 
Anonymous, 2016. Causes of low yield of cotton during cotton crop season 2015. Report of committee constituted by Department of Agriculture, Punjab. University of Agriculture, Faisalabad. pp. 49.

Agegnehu G, Ghizaw A and Sinebo W, 2006. Yield performance and land-use efficiency of barley and faba bean mixed cropping in Ethiopian highlands. Eur. J. Agron. 25: 202-207.

Duchene O, Vian J F and Celette F, 2017. Intercropping with legume for agroecological cropping systems: complementarity and facilitation processes and the importance of soil microorganisms. A review. Agric. Ecosys. Environ. 240:148-161

Government of Pakistan, 2016. Pakistan statistical year book. Government of Pakistan, Statistics Division, Pakistan Bureau of Statistics, Islamabad, Pakistan.

Jayakumar M, Ponnuswamy K, Amanullah MM, Yassin MM and Balasubramanian V, 2008. Influence of intercropping and sources of nitrogen on yield attributes yield and economic of cotton. Res. J. Agric. Biol. Sci. 4: 149-153.

Khan MB and Khaliq A, 2004. Study of mungbean intercropping in cotton planted with different techniques. J. Res. (Sci). 15: 23-31.

Khan MB, Akhtar M and Khaliq A, 2001. Effect of planting patterns and different intercropping systems on the productivity of cotton (Gossypium hirsutum L.) under irrigated conditions of Faisalabad. Int. J. Agric. Biol. 03: 432-435.

Korres NE and Froud-Williams RJ, 2002. Effects of winter wheat cultivars and seed rate on the biological characteristics of naturally occurring weed flora. Weed Res. 42: 417-428.

Legwaila GM, Marokane TK and Mojeremane W, 2012. Effects of intercropping on the performance of maize and cowpeas in Botswana. Int. J. Agric. Forest. 2:307-310.

Li L, Sun JH, Zhang FS, Li XL, Yang SC and Rengel Z, 2001. Wheat/maize or wheat/soybean strip intercropping. I. Yield ad-vantage and interspecific interactions on nutrients. Field Crops Res. 71:123-137.

Lithourgidis AS, Vlachostergios DN, Dordas CA and Damalas CA, 2011a. Dry matter yield, nitrogen content, and competition in pea-cereal intercropping systems. Eur. J. Agron. 34: 287-294
Lithourgidis AS, Dordas CA, Damalas CA and Vachostergios DN, 2011b. Annual intercrops: an alternative pathway for sustainable agriculture. Aust. J. Crop Sci. 5: 396-410.

Metwally AA, Shafik MM, Sherief MN and AbdelWahab TI, 2012. Effect of intercropping corn on Egyptian cotton characters. J. Cotton Sci. 16: 210219.

Ministry of Finance Pakistan, 2018. Economic Survey of Pakistan. Ministry of Finance, Government of Pakistan, Islamabad, Pakistan.

Morgado LB and Willey RW, 2008. Optimum plant population for maize-bean intercropping system in the Brazilian semi-arid region. Sci. Agric. (Piracicaba, Braz.). 65: 474-480. http://dx.doi.org/10.1590/S010390162008000500005.

Rusinamhodzi L, Murwira HK and Nyamangara, 2006. Coton-cowpea intercropping and its $\mathrm{N}_{2}$ fixation capacity improves yield of subsequent maize crop under Zimbabwean rain-fed conditions. Plant Soil. 286: 327-336.

Safina SA, Noaman AH and Metwally AA, 2014. Productivity and Fiber Quality of Two Egyptian Cotton Cultivars Under Solid and Intercropping Cultures With Maize. Int. J. Agric. Crop Sci. 7: 778-785.

Santalla M, Rodino AP, Casquero PA and de Ron AM, 2001. Interactions of bush bean intercropped with field and sweet maize. Eur. J. Agron. 15: 185-196.

Vandermeer JH, 1989. The ecology of intercropping. Cambridge University Press, Cambridge, UK.

Williams AC and McCarthy BC, 2001. A new index of interspecific competition for replacement and additive designs. Ecol. Res. 16: 29-40.

\section{Contribution of Authors}

Khan MN: Conceived idea and designed research methodology, manuscript final reading and approval

Shoaib M: Literature review and manuscript writing

Ashraf MS: Data collection and analysis

Qamar R: Data collection and analysis

Mahboob A: Data analysis and interpretation

Ijaz S: Literature review and data collection 